\title{
Prevalence and Characterization of Antibiotic-Resistant Staphylococcus aureus Recovered from Pasteurized Cheese Commercialized in Panama City Markets
}

\author{
Fermín Mejía, ${ }^{1}$ Nohelia Castro-del Campo, ${ }^{2}$ Arleny García, ${ }^{1}$ Katerine Rodríguez, ${ }^{1}$ \\ Humberto Cornejo, ${ }^{1}$ Sara Ahumada-Ruiz, ${ }^{1,3}$ Marcela Soto-Beltrán, ${ }^{2}$ Maricela Castillo, ${ }^{4}$ \\ Jordi Querol-Audi, ${ }^{1,5}$ Cristobal Chaidez-Quiroz, ${ }^{2}$ and Alex O. Martínez-Torres $\mathbb{D}^{1}$ \\ ${ }^{1}$ Laboratory of Experimental and Applied Microbiology, University of Panama, Panama, Panama \\ ${ }^{3}$ Panamanian Food Safety Authority, Panama City, Panama \\ ${ }^{2}$ Laboratorio Nacional para La Investigación en Inocuidad Alimentaria (LANIIA) \\ Del Centro de Investigación en Alimentación y Desarrollo (CIAD), Sinaloa, Mexico \\ ${ }^{4}$ Panama Canal Authority, Panama City, Panama \\ ${ }^{5}$ Sistema Nacional de Investigación (SNI) SENACYT, Panama City, Panama
}

Correspondence should be addressed to Alex O. Martínez-Torres; amartinet13@gmail.com

Received 25 March 2021; Revised 6 July 2021; Accepted 13 October 2021; Published 12 November 2021

Academic Editor: Amarat (Amy) Simonne

Copyright (C) 2021 Fermín Mejía et al. This is an open access article distributed under the Creative Commons Attribution License, which permits unrestricted use, distribution, and reproduction in any medium, provided the original work is properly cited.

\begin{abstract}
Foodborne bacteria, with a high degree of antibiotic resistance, play an important role in the morbidity and mortality of gastrointestinal diseases worldwide. Among 250 disease-causing bacteria, Staphylococcus aureus is one of the major causes of food poisoning, and its resistance to multiple antimicrobials remains of crucial concern. Cheese is often contaminated when proper sanitary procedures are not followed during its production and marketing. This work aimed to evaluate the microbiological quality of pasteurized white cheese commercialized in Panama City. Cheese from five different brands sold in local supermarkets were selected to determine the presence of $S$. aureus as well as its antibiotic resistance profile. The results showed significant contamination of $S$. aureus with a geometric median sample of $10^{4}-10^{7} \mathrm{CFU} / \mathrm{g}$. Four out of five $(4 / 5)$ cheese brands analyzed presented risk of food poisoning by exceeding the allowed range of consumption with a geometric median sample of $1,8 \times 10^{6}-1,4 \times 10^{7} \mathrm{CFU} /$ g. Fourteen different resistance phenotypes were found. Fifty-five percent (55\%) of the analyzed strains were resistant to erythromycin. The data confirm a relatively high prevalence and high levels of $S$. aureus, most likely originated during handling in Panama City retail markets. Further studies are needed to reduce bacterial contamination and to decrease the risk of food poisoning in the consumption of pasteurized cheese.
\end{abstract}

\section{Introduction}

Cheese, characterized by its snow-white color, crumbly texture, and a lightly salted flavor is an essential ingredient of Panamanian cuisine. Cheese is rich in nutrients, including vitamins, proteins, lactose, fats, minerals, and water. Therefore, cheese favors the growth and survival of bacterial enteric pathogens such as Listeria monocytogenes (L. monocytogenes), Salmonella, Shiga-toxin producing Escherichia coli (STEC), and Staphylococcus aureus
(S. aureus) [1-4]. Hand manipulation of processed cheese along with its high moisture content and barely acidic $\mathrm{pH}$ are factors that contribute to the presence and growth of foodborne pathogens [5, 6]. In Panama, cheese is either sold to wholesalers or directly to end consumers, usually in small markets and/or through door-to-door services, using no labels and undergoing minimum food-safety precautions in its transportation and storage $[5,7,8]$. The lack of hazard analysis and critical control points (HACCP) or good manufacturing practices (GMP) and good hygiene practices 
(GHP) at the processing plant, along with hand manipulation by its personnel, increase the risk of cheese contamination $[9,10]$.

S. aureus is an important foodborne pathogen that causes a wide spectrum of infections in humans, from mild skin infections, bacteremia, systemic disease, or osteomyelitis to more life-threatening infections, such as toxic shock syndrome and staphylococcal food poisoning (SFP) $[11,12]$. $S$. aureus is one of the main causative agents of SFP associated with cheese consumption [13]. In the United States of America (USA) and according to the last report available from 2017, the annual incidence of foodborne outbreaks was 841 resulting in 14,481 illnesses, including 827 hospitalizations and 20 deaths, with 2 of them reported as SFP outbreaks [14]. An estimated 77 million people in the Americas suffer an episode of foodborne illness each year, where children under the age of 5 represent $40 \%$, with 125,000 deaths a year [15]. For example, in Ecuador, a total of 19,487 cases were reported in 2019, 12,203 of which were caused by bacteria, eventhough the specific causative agents were not indicated except for Salmonella and Shigella outbreaks [16]. In Panama, 277,286 illnesses associated with foodborne pathogens were reported in 2019 [17]. However, no updated data about the microorganisms responsible of these outbreaks is available since 2002, when twenty-eight percent $(28 \%)$ of the investigated foodborne outbreaks were related to SFP, while E. coli was responsible for sixty-two percent (62\%) [18].

Antibiotic-resistant $S$. aureus has been isolated from milk and cheese in many parts of the world [19-23]. To exacerbate the food-safety breach of $S$. aureus in cheese, some strains are able to elude antibiotic treatments. These strains, very often referred to as antibiotic resistant strains, have shown multiple antibiotic resistance patterns [21, 24]. This resistance to various antibiotic groups can be mediated by the bacterial chromosome, plasmids, and transposons or gene cassettes that are incorporated into integrons $[25,26]$, thus making the gene transfer among bacterial strains an easier process. Antibiotic resistance among bacteria is a major public health issue as a result of their persistent circulation in the environment and its consequent contamination of cheese [27]. Besides monitoring the antibiotic resistance of $S$. aureus in cheese, it is of great importance to prevent the spread of multidrug-resistant strains, which may have multiple undesirable consequences. Therefore, the aim of this study was to evaluate $S$. aureus concentration levels and its antibiotic resistance pattern, present in locally produced and commercialized pasteurized cheese in Panama City.

\section{Materials and Methods}

2.1. Study Area and Sample Collection. A total of five brands of pasteurized fresh white cheese sold in Panama City were analyzed. Five samples of each pasteurized fresh white cheese brand were collected from different independent local supermarkets, where all these cheeses are wrapped and kept under refrigeration at $4^{\circ} \mathrm{C}$. Sample collections were done in five field visits in a row and were placed in sterile bags, numbered, and brought in the cold chain to the Laboratory of Experimental and Applied Microbiology (LAMEXA) of the University of Panama and stored at $4^{\circ} \mathrm{C}$ until processing. The analysis was carried within $24 \mathrm{~h}$ upon collection.

2.2. Isolation and Identification of S. aureus. S. aureus was isolated and counted using the method described in the bacteriological analytical methods [28]. Briefly, $25 \mathrm{~g}$ of each sample was weighed aseptically into sterile stomacher bags (Seward Medical Stomacher Bags ${ }^{\odot}$ Seward, Germany) containing $225 \mathrm{~mL}$ of sterilized $0.1 \%$ (w/v) peptone water (Difco, Mexico City, MEX) and homogenized for $2 \mathrm{~min}$, followed by serial 10 -fold dilutions until $1 \times 10^{-6}$.

Bacteriological analysis was performed by plating $0.1 \mathrm{~mL}$ of each dilution into triplicates on Baird-Parker agar (BP, Oxoid, Basingstoke, Hampshire, UK), supplemented with egg yolk tellurite emulsion (Oxoid, Basingstoke, Hampshire, $\mathrm{UK})$. All the analyses were conducted under aseptic conditions. The plated cultures were then incubated at $37^{\circ} \mathrm{C}$ for $48 \mathrm{~h}$. Colonies that exhibited the characteristics of $S$. aureus morphology (circular black colonies with an opaque zone within an outer clear zone) were considered for further confirmation.

2.3. Coagulase Test and Enumeration of S. aureus. All presumptive $S$. aureus isolates were subjected to the coagulase test as described by Koneman et al. [29]. The number of S. aureus was reported as CFU/g of a tested sample, taking into account the total colonies counted (TC), the number of coagulase-confirmed colonies (CC), the selected presumptive colonies (SC), the dilution (D), and inoculated volume (V) onto BP agar. The formula employed is

$$
\frac{\mathrm{CFU}}{g}=(\mathrm{TC} \times \mathrm{CC}) \div((\mathrm{SC}) \times(D) \times(V)) \text {. }
$$

\subsection{Assessment of the Microbiological Quality of Pasteurized} Cheese. According to guidelines set by the Laboratory Methods in Food Microbiology (LMFM) [30], the microbiological quality of pasteurized cheese can be grouped into two different categories based on their bacterial counts of S. aureus: (1) acceptable and (2) unacceptable/potentially hazardous. A cheese sample with $S$. aureus counts, greater or equal to $1 \times 10^{3} \mathrm{CFU} / \mathrm{g}$, is considered unhealthy for human consumption; therefore, it fits into category (2).

2.5. Antibiotic Susceptibility Testing. Coagulase-confirmed S. aureus colonies were tested for susceptibility to different antibiotics, using the disk-agar diffusion method in accordance to the Clinical and Laboratory Standards Institute [31]. Inoculums from each $S$. aureus isolate were grown aerobically in $5 \mathrm{~mL}$ of Müller-Hinton broth (Bioxon, Mexico City, MEX) and were incubated at $37^{\circ} \mathrm{C}$ to reach a turbidity equal to a MacFarland 0.5 standard. Müller-Hinton agar plates were surface inoculated with each $S$. aureus culture using sterile cotton swabs, and antibiotic impregnated disks (BD Diagnostics, Mexico City, 
MEX) were placed on the surface of the inoculated agar plates. A reference strain of $S$. aureus (ATCC 6538) was used as a control. Antibiotics tested were erythromycin $(E)$ $(15 \mu \mathrm{g})$, tetracycline (TE) $(30 \mu \mathrm{g})$, gentamicin (GEM) $(10 \mu \mathrm{g})$, vancomycin (VA) $(30 \mu \mathrm{g})$, oxacillin (OX) $(1 \mu \mathrm{g})$, chloramphenicol (CHL) $(30 \mu \mathrm{g})$, clindamycin (CC) $(2 \mu \mathrm{g})$, ofloxacin (OFX) $(5 \mu \mathrm{g})$, and rifampicin (RA) $(5 \mu \mathrm{g})$. Plates were incubated at $37^{\circ} \mathrm{C}$ for $18-24 \mathrm{~h}$, and inhibition zone sizes were measured. Isolates were classified as resistant, intermediate, or susceptible to a particular antibiotic following the Clinical and Laboratory Standards Institute criteria [31]. Details of the antimicrobials used in this study are given in Table 1.

2.6. Statistical Analysis. Statistical differences were determined by performing a variance analysis with a significant level of $0.05 \%$. The software SPSS Statistic 22 [32] was used for the analysis, and a $p$ value $\leq 0.01$ was considered statistically significant.

\section{Results}

3.1. Bacteriological Counts and Microbiological Quality of Pasteurized Cheese. A total of 25 pasteurized cheese samples from five different brands (five samples per brand) were screened for the presence of $S$. aureus (Figure 1). All the suspected $S$. aureus colonies were subjected to the coagulase test for confirmation. Coagulase-positive colonies were counted, and the levels of contamination of each brand were determined, giving the following results: the five samples analyzed from brand 1 were positive for the presence of S. aureus with a mean value of $6 \times 10^{3} \mathrm{CFU} / \mathrm{g}$; two positive samples were detected in brand 2 (mean value of $2 \times 10^{4} \mathrm{CFU} / \mathrm{g}$ ); four positive samples in brand 3 (mean value of $1.6 \times 10^{4} \mathrm{CFU} / \mathrm{g}$ ); and 1 positive sample in brand 5 (mean value of $3.6 \times 10^{4} \mathrm{CFU} / \mathrm{g}$ ). Thus, according to the Laboratory Methods in Food Microbiology, these four brands of pasteurized cheese are considered unsatisfactory for human consumption. On the other hand, brand 4 did not show any contamination by $S$. aureus, and therefore, its consumption is safe.

3.2. Antibiotic Susceptibility of S. aureus Isolates. Nine antimicrobial agents of veterinary and human health relevance, from different antibiotic classes, were tested. A total of one hundred S. aureus isolates were analyzed for antimicrobial susceptibility. Forty-nine of them were resistant to at least one of the antibiotics tested. A summary of the percentage of S. aureus strains, resistant to these antibiotics, is provided in Table 1. From all the examined brands, we were able to detect $S$. aureus isolates showing susceptibility to some of the following six antibiotics: GEM, VA, OX, OFX, TE, and RA (Table 1). By contrast, fifty-five percent $(55 \%)$ of the S. aureus isolates tested showed no susceptibility to E. An intermediate resistance to CHL and CC was observed in fifty-one percent $(51 \%)$ and thirty-seven (37\%) of the isolates, respectively. However, a significant resistance to CC was observed in thirty-five (35\%) of the S. aureus isolates (Table 1). Although it is not one of the highest levels of resistance encountered in the study, the result is still startling, considering CC as one of the most common antibiotics used to treat nonlife-threatening human infections with S. aureus.

Susceptibility to two or more of the nine antibiotics tested was observed in forty-two percent $(42 \%)$ of the S. aureus isolates (21 out of 49). A total of fourteen distinct antibiotic multiresistance profiles were detected (Table 2). Pattern A showed 4 phenotype resistance profiles to two antibiotics (A1-A4) and was expressed by seven isolates (14\%): A1 with four isolates showing resistance to E-TE; pattern B1-B6 showed resistance to three antibiotics $(20 \%$, 9/49) including the resistance profile to CC; pattern C1, C2, and D1 exhibited resistance to four antibiotics $(4 \%, 2 / 49)$ and to five antibiotics $(2 \%, 1 / 49)$, respectively. One out of the forty-nine $S$. aureus isolates showed resistance to eight out of the nine antibiotics being tested. The results showed a multidrug resistance profile to more than two agents from different antibiotic classes in twenty $S$. aureus isolates out of forty-nine representing forty-two percent (42\%). Multidrug resistance is frequently found in strains of human origin, whereas in veterinary medicine, it is occasionally reported $[33,34]$. The brands with the highest antibiotic resistance profiles were 2 (8 antibiotic resistances) and 5 (6 resistances), followed by 1 and 3 with 5 and 2 antibiotic resistances, respectively.

\section{Discussion}

S. aureus is a foodborne pathogen that has been linked to various types of foodborne outbreaks related to the consumption of cheese, which have caused a significant impact on health, economic, and trade issues. Regarding to the analyzed five pasteurized cheese brands, four of them were not suitable for human consumption due to the high levels of bacteria found [35], according to guidelines set by the Laboratory Methods in Food Microbiology (LMFM) [30]. A cheese sample with $S$. aureus counts, greater or equal to $1 \times 10^{3} \mathrm{CFU} / \mathrm{g}$, is considered unhealthy for human consumption, concluding that only brand 4 fits the criteria. The coagulase test is a tool to discriminate Staphylococcus pathogenic species [36]. In the present study, the total prevalence of coagulase-positive staphylococci was eighty percent $(80 \%)$. The rate of contamination is higher than that observed in the survey conducted by Normano et al. [27], in which the total prevalence of coagulase-positive staphylococci in dairy products was only $17.3 \%$. Nusrat et al. [37] showed that forty-seven percent $(47 \%)$ of cheese samples harbored S. aureus. The presence of coagulase-positive Staphylococcus in the cheese analyzed in this study, elaborated with pasteurized milk, may be an indicative of sanitary deficiencies in the storage and retailing of the product [27]. On the other hand, it has been demonstrated that $S$. aureus may enter via contaminated raw milk due to subclinical mastitis in cows, and due to improper food handling, it may promote its colonization throughout the processing plant and consequently contaminate the final product $[9,38,39]$. The robustness of $S$. aureus in food increases the risk of staphylococcal enterotoxins production because the bacteria 
Table 1: Antibiotic resistance profiles of S. aureus isolates from five pasteurized cheese brands in Panama.

\begin{tabular}{|c|c|c|c|c|c|c|c|c|c|c|}
\hline \multirow[t]{2}{*}{ Class of antibiotic } & \multirow[t]{2}{*}{ Antibiotic } & \multirow[t]{2}{*}{ Abbreviation } & \multicolumn{3}{|c|}{$\begin{array}{l}\text { Inhibition zone } \\
(\mathrm{mm})^{\mathrm{a}}\end{array}$} & \multicolumn{5}{|c|}{ Antibiotic profile } \\
\hline & & & $R^{b}$ & $I$ & $S$ & 1 & 2 & 3 & 5 & $T(\%)$ \\
\hline Macrolides & Erythromycin & $\mathrm{E}(15)^{\mathrm{c}}$ & $\leq 12$ & $13-17$ & $\geq 18$ & $4-12-3^{d}$ & $0-2-0$ & $5-3-0$ & $18-2-0$ & $55-39-6$ \\
\hline Tetracyclines & Tetracycline & TE (30) & $\leq 14$ & $15-20$ & $\geq 21$ & $1-8-10$ & $0-1-1$ & $6-1-1$ & $5-4-11$ & $24-29-47$ \\
\hline Aminoglycosides & Gentamicin & GEN (10) & $\leq 13$ & $14-22$ & $\geq 23$ & 0-0-19 & $0-0-2$ & $1-3-4$ & $0-2-18$ & $2-10-88$ \\
\hline Glycopeptides & Vancomycin & VA (30) & $\leq 12$ & $13-14$ & $\geq 15$ & $0-0-19$ & $0-0-2$ & $0-0-8$ & $1-1-18$ & $2-2-96$ \\
\hline Penicillinase-stable penicillin & Oxacillin & OX (1) & $\leq 12$ & $13-15$ & $\geq 16$ & 0-0-19 & $1-1-0$ & $4-0-4$ & $5-1-14$ & $20-4-76$ \\
\hline Phenicols & Chloramphenicol & CHL (30) & $\leq 10$ & $11-12$ & $\geq 13$ & $1-13-5$ & $0-0-2$ & $1-6-1$ & $0-6-14$ & $4-51-45$ \\
\hline Lincosamide & Clindamycin & CC (2) & $\leq 16$ & $17-19$ & $\geq 20$ & $3-12-4$ & $1-1-0$ & $7-1-0$ & $6-4-10$ & $36-36-28$ \\
\hline Fluoroquinolones & Ofloxacin & OFX (5) & $\leq 14$ & $15-18$ & $\geq 19$ & $0-0-19$ & $0-1-1$ & $2-2-4$ & $1-5-14$ & $6-16-78$ \\
\hline Asamycins & Rifampicin & $\mathrm{RA}(5)$ & $\leq 9$ & $10-11$ & $\geq 12$ & $1-2-16$ & $0-0-2$ & $3-2-3$ & $0-3-17$ & $6-14-80$ \\
\hline
\end{tabular}

E, erythromycin; TE, tetracycline; GEM, gentamicin; VA, vancomycin; OX, oxacillin; CHL, chloramphenicol; CC, clindamycin; OFX, ofloxacin; RA, rifampicin. ${ }^{a}$ The concentrations used inhibition zone measurements according to the Clinical and Laboratory Standards Institute [31]. ${ }^{\mathrm{b}} \mathrm{Abbreviation:} R$, resistant; $I$, intermediate; $S$, susceptible; $T$, total. ${ }^{\circ}$ The antibiotic disc concentration in $\mu \mathrm{g}$ is shown in parenthesis. ${ }^{\mathrm{d}}$ Number of resistant, intermediate, and susceptible isolated strains.

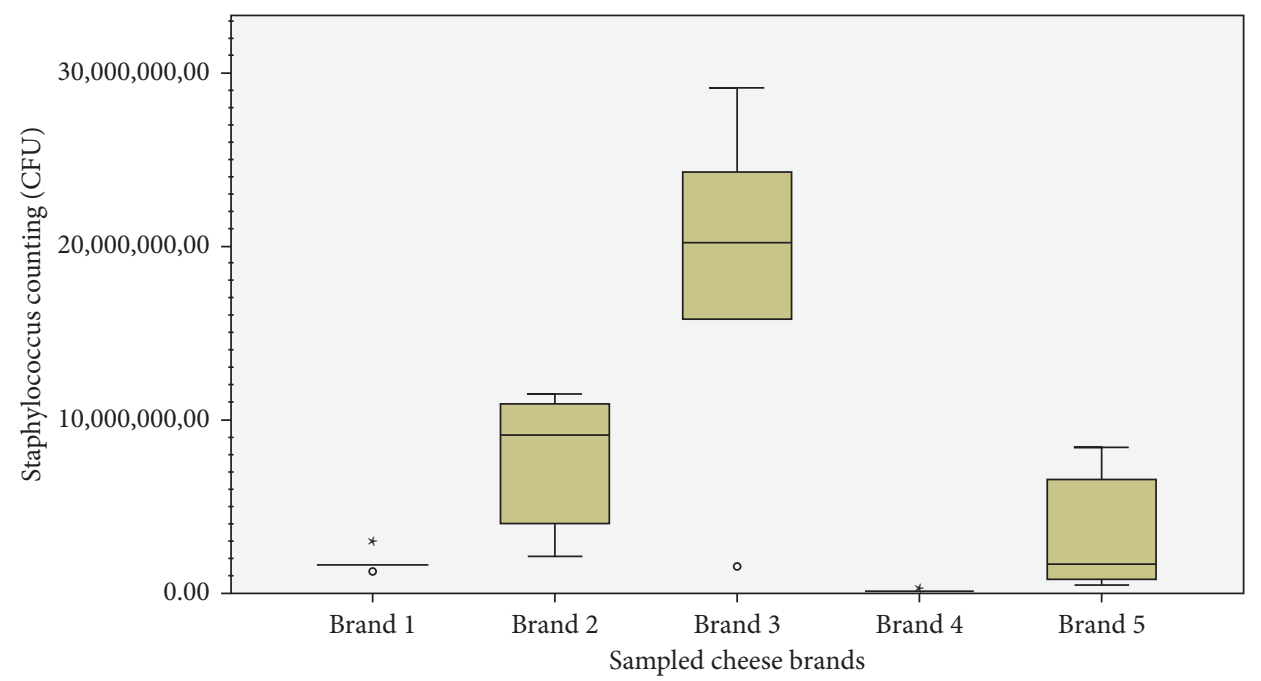

Figure 1: S. aureus CFU/g of pasteurized cheese for each brand analyzed. Boxes (in gray color) and error bars (in black) represent the median and standard deviation according to the Kruskal-Wallis statistical test.

TABle 2: Antibiotic resistance profiles of $S$. aureus isolates from pasteurized cheese.

\begin{tabular}{|c|c|c|c|c|c|}
\hline \multirow{2}{*}{$\begin{array}{l}\text { Antibiotic resistance } \\
\text { phenotype }\end{array}$} & \multirow{2}{*}{ Pattern } & \multicolumn{4}{|c|}{ Isolates (\%) } \\
\hline & & 1 & 2 & 3 & 5 \\
\hline E-TE & A1 & $1(2)$ & & & $3(6)$ \\
\hline CC-E & $\mathrm{A} 2$ & $1(2)$ & & & \\
\hline CC-TE & A3 & & & $1(2)$ & \\
\hline CC-OFX & A4 & & $1(2)$ & & \\
\hline CC-E-RA & B1 & $1(2)$ & & & \\
\hline OX-CHL-RA & B2 & & $1(2)$ & & \\
\hline OX-CC-TE & B3 & & $1(2)$ & & $1(2)$ \\
\hline CC-E-TE & B4 & & $3(6)$ & & \\
\hline OX-CC-E & B5 & $2(4)$ & & & \\
\hline CC-E-OFX & B6 & & & & $1(2)$ \\
\hline VA-OX-CC-E & $\mathrm{C} 1$ & & & & $1(2)$ \\
\hline OX-CC-E-TE & $\mathrm{C} 2$ & & & & $1(2)$ \\
\hline OX-CC-E-TE-RA & D1 & & $1(2)$ & & \\
\hline GEM-OX-CC-E-OFX-TE-RA & E1 & & $1(2)$ & & \\
\hline
\end{tabular}

E, erythromycin; TE, tetracycline; GEM, gentamicin; VA, vancomycin; OX, oxacillin; CHL, chloramphenicol; CC, clindamycin; OFX, ofloxacin; RA, rifampicin. ${ }^{\text {aT }}$ The total number of isolates and its corresponding percentage (in parenthesis) are given. can only be eliminated through a thermal process, but the toxins may remain and cause SFP [40, 41]. The diagnostic criterion for SFP is based upon the detection and recovery of $1 \times 10^{5} \mathrm{CFU} / \mathrm{g}$ of $S$. aureus $[11,42]$. Coagulase-positive colonies counted were $6 \times 10^{3} \mathrm{CFU} / \mathrm{g}$ for brand 1 and $3.6 \times 10^{4} \mathrm{CFU} / \mathrm{g}$ for brand 5 (Figure 1), and thus, both meet the diagnostic criterion for SFP that is based upon the detection and recovery of less than $1 \times 10^{5} \mathrm{CFU} / \mathrm{g}$ of $S$. aureus. However, since values are high, especially for brand 5 , it would be worthy to analyze the presence of $S$. aureus toxins that would represent a risk for public health. The lack of critical control points in the production process of cheese may also contribute to the survival and outgrowth of the pathogen [10], although we cannot exclude that handling conditions at the supermarket level might have also an impact. Thus, these results indicate an urgent need for implementation of food hygiene standards in the food industry.

On the other hand, the use and inappropriate prescriptions of antibiotics in the public, private, and agricultural sectors are considered the main factors of the increase in bacterial antimicrobial resistance $[43,44]$. High levels of 
antibiotic resistance were found in this study. A high percentage of resistance to erythromycin was observed, and this may be attributed to its frequent use in the treatment of human infections. In fact, both nasal and hand contamination of food from food handlers with multiresistant and virulent $S$. aureus has been reported. For example, antibiotic resistant and enterotoxin gene-positive $S$. aureus have been isolated from nasal swabs and hand fingerprints of food handlers in central Iran, Hong Kong, Portugal, or Malaysia [45-48].

Intermediate resistance of $S$. aureus to clindamycin and chloramphenicol can be due to their use in veterinary medicine. Rivera-Salazar et al. [21] reported a high frequency of S. aureus antibiotic resistance (56\% of the isolates) from pasteurized and unpasteurized cheese samples from Venezuela. Penicillin (44\%), oxacillin (20\%), tetracycline (12\%), erythromycin (8\%), amikacin (8\%), kanamycin (4\%), ciprofloxacin (4\%), and clindamycin (4\%) are in agreement with our results. On the other hand, Nusrat et al. [37] found higher levels of S. aureus resistance to methicillin (58.8\%) and oxacillin (100\%) from cheese samples in Bangladesh. The results of the present study demonstrated that S. aureus isolates from pasteurized cheese in Panamanian markets were resistant to antibiotics from the macrolides class. These results are in agreement with Montoya's [49], which showed S. aureus resistance to macrolides such as erythromycin and clindamycin from the lincosamide class. Multidrug resistance was observed in forty-two percent (42\%) of the $S$. aureus isolates, including all the antibiotic classes used in the present study (Table 2), as reported by Rivera-Salazar et al. [21]. Whether the differences in the antibiotic resistance profile observed in our work compared with those reported by Nusrat et al. [37] are due to different cheese characteristics (such humidity or acidity), manufacturing, distribution, or handling cannot be addressed, since authors do not describe these data. It would be interesting to study if the antibiotic resistance profiles of $S$. aureus isolates from food handlers as a source of dissemination would explain these differences between regions.

\section{Conclusions}

The occurrence of $S$. aureus in pasteurized cheese sold in Panama City's retail markets possesses a risk for consumers of these food items. The low microbiological quality of pasteurized cheese in Panama City markets suggests that the bacterium is likely to be found in other Panamanian markets with similar or even poorer sanitary conditions, justifying worker-vendor training and further research on the persistence of the pathogen, as well as the application of effective corrective actions at the market level. Consequently, continuous surveillance of $S$. aureus in Panamanian retail markets will help identify pathogenic sources and promote the development of better practices for processing and selling food. It should also improve the legislative framework that governs the presence of pathogens in food. Lastly, these data confirm that good hygienic practices and temperature control are critical for $S$. aureus control and prevention in food at retail markets.

\section{Data Availability}

No data were used to support this study.

\section{Conflicts of Interest}

The authors declare that they have no conflicts of interest.

\section{Acknowledgments}

This work was supported in part by the Sistema Nacional de Investigación (SNI) of Secretaría Nacional de Ciencia, Tecnología e Innovación (Panamá). The authors also thank Jacinto Ariel Pérez for his support in the data statistical analysis.

\section{References}

[1] C. M. B. S. Pintado, A. Oliveira, M. E. Pampulha, and M. A. S. S. Ferreira, "Prevalence and characterization of Listeria monocytogenes isolated from soft cheese," Food Microbiology, vol. 22, no. 1, pp. 79-85, 2005.

[2] J. R. F. Brito, E. M. P. Santos, E. F. Arcuri et al., "Retail survey of Brazilian milk and minas frescal cheese and a contaminated dairy plant to establish prevalence, relatedness, and sources of Listeria monocytogenes isolates," Applied and Environmental Microbiology, vol. 74, no. 15, pp. 4954-4961, 2008.

[3] A. H. Soomro, M. A. Arain, M. Khashkeli, B. Bhutto, and A. Q. Memon, "Isolation of Staphylococcus aureus from milk products sold at sweet-meat shops of hyderabad," Journal of Biological Sciences, vol. 3, pp. 91-94, 2003.

[4] K. Farzana, N. H. S. Syed, and J. Farzana, "Antibiotic resistance pattern against various isolates of Staphylococcus aureus from raw milk samples," Journal of Scientific Research, vol. 15, pp. 145-151, 2004.

[5] V. A. Cesin, M. Aliphat Fernandeza, B. Ramirez Valverdea, J. G. Herrera Haroa, and C. D. Marinez, "Family milk and cheese production. A study in three communities in the municipality of tetlatahuca in the state of tlaxcala, Mexico," Tecnica Pecuaria en Mexico, vol. 45, pp. 61-76, 2007.

[6] P. D. M. McDonald, R. E. Whitwam, J. D. Boggs et al., "Outbreak of listeriosis among Mexican immigrants as a result of consumption of illicitly produced Mexican-style cheese," Clinical Infectious Diseases, vol. 40, pp. 677-682, 2005.

[7] C. Vazquez-Salinas, O. Rodas-Suarez, and E. I. QuinonesRamirez, "Occurrence of Listeria species in raw milk in farms on the outskirts of Mexico city," Food Microbiology, vol. 18, pp. 177-181, 2001.

[8] R. I. Moreno-Enriquez, A. Garcia-Galaz, E. Acedo-Felix et al., "Prevalence, types, and geographical distribution of Listeria monocytogenes from a survey of retail queso fresco and associated cheese processing plants and dairy farms in sonora, Mexico†," Journal of Food Protection, vol. 70, no. 11, pp. 2596-2601, 2007.

[9] M. C. D. P. B. André, M. R. H. Campos, L. J. Borges, A. Kipnis, F. C. Pimenta, and Á. B. Serafini, "Comparison of Staphylococcus aureus isolates from food handlers, raw bovine milk and Minas Frescal cheese by antibiogram and pulsed-field gel electrophoresis following SmaI digestion," Food Control, vol. 19, no. 2, pp. 200-207, 2008.

[10] M. Kousta, M. Mataragas, P. Skandamis, and E. H. Drosinos, "Prevalence and sources of cheese contamination with 
pathogens at farm and processing levels," Food Control, vol. 21, no. 6, pp. 805-815, 2010.

[11] J. Kadariya, T. C. Smith, and D. Thapaliya, "Staphylococcus aureusand staphylococcal food-borne disease: an ongoing challenge in public health," BioMed Research International, vol. 2014, Article ID 827965, 9 pages, 2014.

[12] Centers for Disease Control and Prevention, National Center for Emerging and Zoonotic Infectious Diseases (NCEZID), Division of Foodborne, Waterborne, and Environmental Diseases (DFWED), Centers for Disease Control and Prevention, Atlanta, GA, USA, 2018, https://www.cdc.gov/foodsafety/ diseases/staphylococcal.html. Page last reviewed.

[13] Y.-C. Chiang, W.-W. Liao, C.-M. Fan, W.-Y. Pai, C.-S. Chiou, and H.-Y. Tsen, "PCR detection of Staphylococcal enterotoxins (SEs) N, O, P, Q, R, U, and survey of SE types in Staphylococcus aureus isolates from food-poisoning cases in Taiwan," International Journal of Food Microbiology, vol. 121, no. 1, pp. 66-73, 2008.

[14] Centers for Disease Control and Prevention, "Surveillance for foodborne disease outbreaks-United Sates," National Center for Emerging and Zoonotic Infectious Diseases (NCEZID), Division of Foodborne, Waterborne, and Environmental Diseases (DFWED), https://www.cdc.gov/fdoss/annual-reports/ index.html. Page last reviewed, Centers for Disease Control and Prevention, Atlanta, GA, USA, 2017, https://www.cdc. gov/fdoss/annual-reports/index.html. Page last reviewed.

[15] La inocuidad de los alimentos es responsabilidad de todos, Organización Panamericana de la Salud, Washington, NJ, USA, 2021, https://www3.paho.org/pan/index.php? option=com_content\&view=article\&id=1236:la-inocuidadde-los-alimentos-es-responsabilidad-de-todos\&Itemid $=442$.

[16] Ministerio de Salud Pública, Enfermedades transmitidas por agua y alimentos. Subsistema de vigilancia SIVE-Alerta. Subsecretaría de Vigilancia de la Salud Pública. Dirección Nacional de Vigilancia Epidemiológica. Ecuador. https://www.salud.gob. ec/wp-content/uploads/2021/01/Etas-SE-03.pdf, 2021.

[17] M. de Salud, Boletín epidemiológico semanal. Semana № 52 . Departamento Nacional de Epidemiología. Dirección General de Salud Pública. Panamá. http://minsa.b-cdn.net/sites/default/ files/publicacion-general/boletin_epidemiologico_sem_52_2019. pdf, 2021.

[18] Q. Alleyne and A. George, La Salud de las Américas, Editorial PAHO Scientific and Technical Publication, Washington, NJ, USA, 2002.

[19] G. G. Zhanel, T. L. Hisanaga, N. M. Laing et al., "Antibiotic resistance in outpatient urinary isolates: final results from the north American urinary tract infection collaborative alliance (NAUTICA)," International Journal of Antimicrobial Agents, vol. 26, no. 5, pp. 380-388, 2005.

[20] C. N. Ateba, M. Mbewe, M. Moneoang, and C. Bezuidenhout, "Antibiotic-resistant Staphylococcus aureus isolated from milk in the mafikeng area, north west province, South Africa," South African Journal of Science, vol. 106, pp. 1-6, 2010.

[21] J. Rivera-Salazar, I. Mujica de Fernández, V. Aranaga-Natera, C. Navarro-Ocando, I. Zabala-Díaz, and L. Atencio-Bracho, "Staphylococcus aureus Procedentes de Quesos: susceptibilidad a Antibióticos y su Relación con Plásmidos," Revista Científica, vol. 3, pp. 202-210, 2011.

[22] D. Daka, G. Silassie, and D. Yihdego, "Antibiotic-resistance Staphylococcus aureus isolated from cow's milk in the hawassa area of south Ethiopia," Annals of Clinical Microbiology and Antimicrobials, vol. 11, pp. 1-6, 2012.

[23] G. Castañeda-Ruelas, M. Soto-Beltrán, and C. ChaidezQuiroz, "Detecting source of Staphylococcus in one small- scale cheese plant in northwestern Mexico," Journal of Food Safety, vol. 37, 2016.

[24] M. Enright, "The evolution of a resistant pathogen-the case of MRSA," Current Opinion in Pharmacology, vol. 3, no. 5, pp. 474-479, 2003.

[25] R. M. Hall and C. M. Collis, "Mobile gene cassettes and integrons: capture and spread of genes by site-specific recombination," Molecular Microbiology, vol. 15, pp. 593-600, 1995.

[26] I. Rychlik, D. Gregorova, and H. Hradecka, "Distribution and function of plasmids in Salmonella enterica," Veterinary Microbiology, vol. 112, no. 1, pp. 1-10, 2006.

[27] G. Normanno, A. Firinu, S. Virgilio et al., "Coagulase-positive Staphylococci and in food products marketed in Italy," International Journal of Food Microbiology, vol. 98, no. 1, pp. 73-79, 2005.

[28] G. A. Lancette and R. W. Bennett, "Staphylococcus aureus and staphylococcal enterotoxins," in Compendium of Methods for the Microbiological Examination of Foods, F. P. Downes and K. Ito, Eds., , 4 edition, 2001.

[29] E. W. Koneman and S. Allen, Koneman. Microbiological Diagnosis: Text and Color Atlas, 2008.

[30] W. Harrigan, Laboratory Methods in Food Microbiology, Academic Press, Cambridge, MA, USA, 3rd edition, 1998.

[31] Clinical and Laboratory Standards Institute (CLSI), Performance Standards for Antimicrobial Susceptibility Testing, Clinical and Laboratory Standards Institute, Wayne, PA, USA, 27th edition, 2017.

[32] IBM, IBM SPSS Statistics 22 Brief Guide, IBM Software Group, Chicago, IL, USA, 2013, http://www.sussex.ac.uk/its/pdfs/ SPSS_Brief_Guide_22.pdf.

[33] K. Valero-Leal, Y. Olivares, A. Perozo et al., "Susceptibilidad a los Agentes Antimicrobianos en Cepas de Staphylococcus aureus Aislados en Leche de Bovino con Mastitis Subclínica y Leche de Tanques," Revista Científica, vol. 20, pp. 367-376, 2010.

[34] M. J. López-Pueyo, F. Barcenilla-Gaite, R. Amaya-Villar, and J. Garnacho-Montero, "Multirresistencia antibiótica en unidades de críticos," Medicina Intensiva, vol. 35, no. 1, pp. 41-53, 2011.

[35] E. W. Rice, R. B. Baird, and A. D. Eaton, Eds., Standard Methods for the Examination of Water and Wastewater, Water Environment Federation, Alexandria, VA, USA, 23th edition, 2017.

[36] A. Foroug, E. Rahimi, A. Shakerian, H. Momtaz, M. Riahi, and M. Momeni, "Antimicrobial resistance of Staphylococcus aureus isolated from bovine, sheeps and goat raw milk," Global Veterinaria, vol. 8, pp. 111-114, 2012.

[37] J. Nusrat, T. N. Ifra, and A. Mrityunjoy, "Detection of methicillin-resistant Staphylococcus aureus within raw milk and cheese samples," International Food Research Journal, vol. 22, pp. 2629-2633, 2015.

[38] G. S. Zendejas-Manzo, H. Avalos-Flores, and M. Y. SotoPadilla, "Microbiología de Staphylococcus aureus: generalidades, Patogenicidad y Métodos de Identificación," Revista Biomédica, vol. 25, pp. 129-143, 2014.

[39] L. Grispoldi, M. Karama, F. Ianni et al., "The relationship between $S$. aureus and branched-chain amino acids content in composite cow milk," Animals, vol. 9, no. 11, p. 981, 2019.

[40] L. Grispoldi, M. Karama, A. Armani, C. Hadjicharalambous, and B. T. Cenci-Goga, "Staphylococcus aureus enterotoxin in food of animal origin and staphylococcal food poisoning risk assessment from farm to table," Italian Journal of Animal Science, vol. 20, no. 1, pp. 677-690, 2021.

[41] J. Schelin, N. Wallin-Carlquist, M. Thorup Cohn, R. Lindqvist, G. C. Barker, and P. Rådström, "The formation 
ofStaphylococcus aureusenterotoxin in food environments and advances in risk assessment," Virulence, vol. 2, no. 6, pp. 580-592, 2011.

[42] J.-A. Hennekinne, M.-L. De Buyser, and S. Dragacci, "Staphylococcus aureusand its food poisoning toxins: characterization and outbreak investigation," FEMS Microbiology Reviews, vol. 36, no. 4, pp. 815-836, 2012.

[43] V. J. Wirtz, A. Dreser, and R. Gonzales, "Trends in antibiotic utilization in eight Latin American countries, 1997-2007," Revista panamericana de salud publica=Pan American journal of public health, vol. 27, no. 3, pp. 219-225, 2010.

[44] T. F. Landers, B. Cohen, T. E. Wittum, and E. L. Larson, "A review of antibiotic use in food animals: perspective, policy, and potential," Public Health Reports, vol. 127, no. 1, pp. 4-22, 2012.

[45] S. Fooladvand, H. Sarmadian, D. Habibi, A. van Belkum, and E. Ghaznavi-Rad, "High prevalence of methicillin resistant and enterotoxin gene-positive Staphylococcus aureus among nasally colonized food handlers in central Iran," European Journal of Clinical Microbiology \& Infectious Diseases, vol. 38, no. 1, pp. 87-92, 2019.

[46] J. Ho, M. V. Boost, M. V. Boost, and M. M. O'Donoghue, "Tracking sources of Staphylococcus aureus hand contamination in food handlers by spa typing," American Journal of Infection Control, vol. 43, no. 7, pp. 759-761, 2015.

[47] A. Castro, C. Santos, H. Meireles, J. Silva, and P. Teixeira, "Food handlers as potential sources of dissemination of virulent strains of Staphylococcus aureus in the community," Journal of Infection and Public Health, vol. 9, no. 2, pp. 153-160, 2016.

[48] W.-L. Seow, N. A. Mahyudin, S. Amin-Nordin, S. Radu, and N. A. Abdul-Mutalib, "Antimicrobial resistance of Staphylococcus aureus among cooked food and food handlers associated with their occupational information in Klang Valley, Malaysia," Food Control, vol. 124, p. 107872, 2021.

[49] I. Montoya, M. Magdalena, I. Álvarez, C. José, and D. Gloria, "Resistencia Inducible a Clindamicina en Staphylococcus aureus Meticilino Resistente," Revista Chilena de Pediatria, vol. 80 , no. 1 , pp. 48-53, 2009, http://www.scielo.cl/scielo. php?pid=S0370-41062009000100006\&script=sci_arttext. 